\title{
EFFECTIVENESS OF AUTOLOGOUS SERUM THERAPY IN CHRONIC URTICARIA: A PROSPECTIVE OBSERVATIONAL STUDY IN TERTIARY CARE HOSPITAL
}

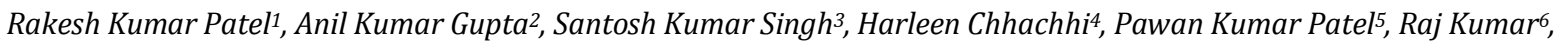
Krishna Gopal Mishra ${ }^{7}$ Manoj Kunwar ${ }^{8}$

1Junior Resident, Department of Dermatology, B. R. D. Medical College, Gorakhpur. 2Associate Professor, Department of Dermatology, B. R. D. Medical College, Gorakhpur. ${ }_{3}^{3}$ Associate Professor, Department of Dermatology, B. R. D. Medical College, Gorakhpur. 4Junior Resident, Department of Dermatology, B. R. D. Medical College, Gorakhpur. 5Junior Resident, Department of Dermatology, B. R. D. Medical College, Gorakhpur. 6Junior Resident, Department of Dermatology, B. R. D. Medical College, Gorakhpur. 7Junior Resident, Department of Dermatology, B. R. D. Medical College, Gorakhpur. §Junior Resident, Department of Dermatology, B. R. D. Medical College, Gorakhpur.

\section{ABSTRACT}

\section{BACKGROUND}

Chronic urticaria is a challenging condition, both for patient and physician in a day-to-day practice. There is constant search for newer modality of treatment, which can provide prolong remission with less side effect. Autologous serum therapy have shown promising result in initial studies.

\section{AIM}

To evaluate effectiveness of Autologous Serum Therapy in chronic urticaria patients.

\section{MATERIALS AND METHODS}

A prospective observational study. Total 220 patients enrolled for study. Autologous serum skin test performed in all patients; 113 patients were given Autologous Serum Therapy along with oral levocetirizine on SOS basis weekly and 107 patients were given only oral levocetirizine on demand basis. Response to treatment assessed by urticaria activity score, urticaria total severity score, antihistamine score, dermatological quality of life index and Likert scale on 2 weekly interval for 10 weeks.

\section{RESULTS}

Autologous Serum Therapy shown significant improvement in both Autologous Serum Skin Test positive and Autologous Serum Skin Test negative patients as compared to non-Autologous Serum Therapy groups. Autologous Serum Therapy is more effective in Autologous Serum Skin Test positive patients.

\section{CONCLUSION}

Autologous Serum Therapy is effective in chronic urticaria patients.

\section{KEYWORDS}

Autologous Serum Therapy Chronic Urticaria, Autologous Serum Skin Test.

HOW TO CITE THIS ARTICLE: Patel RK, Gupta AK, Singh SK, et al. Effectiveness of autologous serum therapy in chronic urticaria: a prospective observational study in tertiary care Hospital. J. Evolution Med. Dent. Sci. 2016;5(17):822-827,

DOI: $10.14260 /$ jemds/2016/190

\section{INTRODUCTION}

Urticaria is defined as a skin lesion consisting of a wheal-andflare reaction in which localized intracutaneous oedema (Wheal) is surrounded by an area of redness (Erythema) that is typically pruritic. ${ }^{1}$ Urticaria persisting beyond 6 weeks are considered chronic. ${ }^{1}$ Antihistamines are the mainstay of management. ${ }^{2}$

Financial or Other, Competing Interest: None.

Submission 23-12-2015, Peer Review 09-02-2016,

Acceptance 15-02-2016, Published 26-02-2016.

Corresponding Author:

Dr. Rakesh Kumar Patel,

Department of Dermatology,

B.R.D. Medical College, Gorakhpur, Uttar Pradesh

E-mail: rakesh99331@gmail.com

DOI: $10.14260 /$ jemds/2016/190

\begin{abstract}
Autologous Serum Therapy.3,4,5,6,7
It is comparatively newer modality of therapy, in which patients own blood is withdrawn and serum is prepared via centrifugation and injected intramuscularly. Initial study has shown that it improves urticaria symptoms, reduces doses of antihistamines and improves quality of life of patients. Basis of this treatment is Autologous serum containing tolerancegenerating anti-idiotype antibodies to mast cell degranulating antigens.
\end{abstract}

\section{MATERIAL AND METHOD}

The study was conducted in tertiary care institute in eastern UP. Institutional ethical committee permission obtained prior to commencement of study. Study design was prospective observational study. Patients were allotted in two groups by systemic random sampling. Informed written consent was taken from all study participants. Chronic urticaria was 
diagnosed clinically as wheal-and-flare reaction, in which localized intracutaneous oedema (Wheal) is surrounded by an area of redness (Erythema) that is typically pruritic. Urticaria persisting beyond 6 weeks are considered chronic. Inclusion criteria includes patient having almost daily appearance of wheals for $\geq 6$ months, patient willing to take part in study and signed written informed consent, patient willing to come for weekly followup for 10 weeks, Age between 18 years to 60 years and free from any infective or immunosuppressive condition. Exclusion criteria were pregnant and lactating women, patient on steroid or other immunosuppressive, patient suffering from any infective condition, addicted to substance abuse. First group was given Autologous Serum Therapy along with oral levocetirizine $5 \mathrm{mg}$ on demand basis and second group was only on oral levocetirizine $5 \mathrm{mg}$ on demand basis.

Baseline investigation performed including complete blood count, liver function test, kidney function test, HIV, HBsAg, serum electrolyte, serum Thyroid Stimulating Hormone level.

\section{Material required for study}

1. Centrifuge machine.

2. Syringe and needle.

3. Vacutainers.

4. Insulin Syringe.

5. Gloves.

6. Normal Saline.

7. Scale.
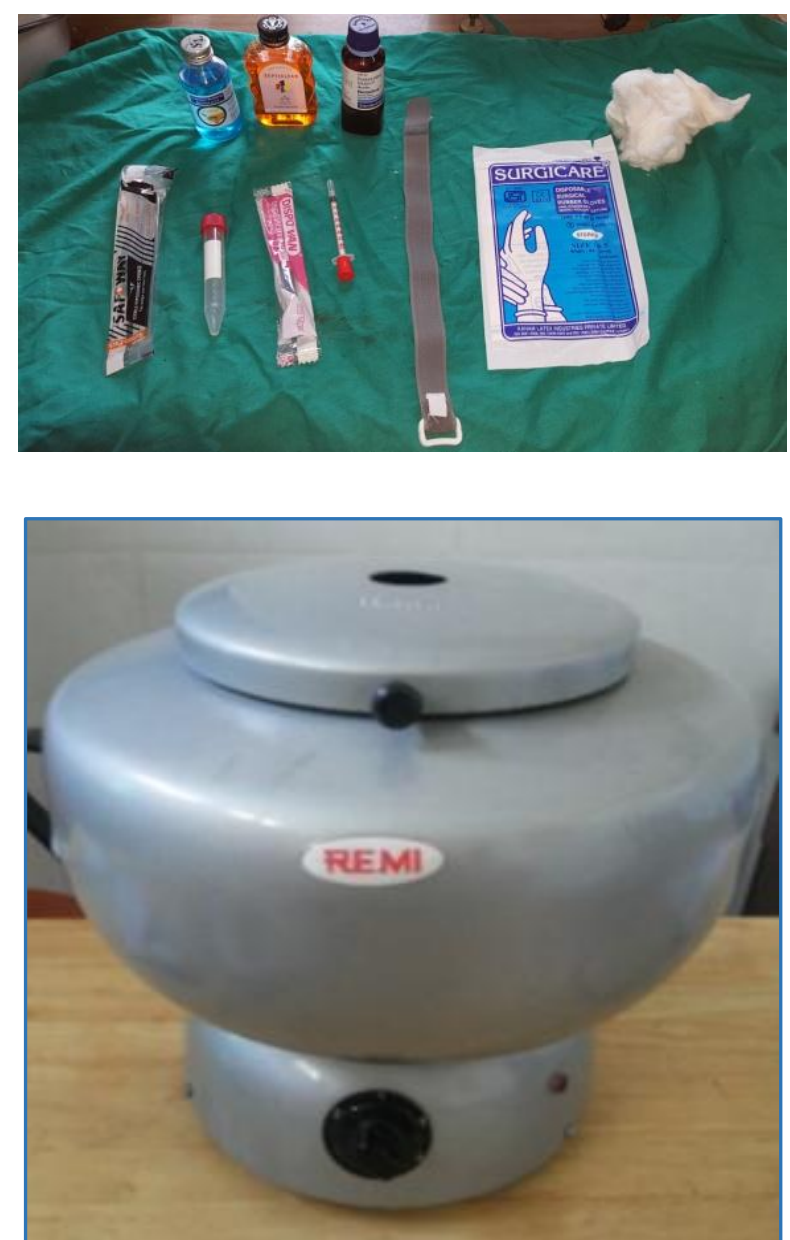

Autologous serum skin test. ${ }^{8}$ was performed by withdrawing $5 \mathrm{~mL}$ blood in disposable syringe under aseptic precaution. Blood is then transferred to disposable vacutainers and centrifuged at 2000rpm for 10 minutes; then upper clear portion which is serum was separated in insulin syringe; $0.02 \mathrm{~mL}$ serum injected in one forearm and normal saline injected in other forearm as control. If test arm erythema was more than $1.5 \mathrm{~mm}$ in perpendicular diameter than that of control then it is considered as Autologous Serum Skin Test positive and less than $1.5 \mathrm{~mm}$ is considered as Autologous Serum Skin Test negative.

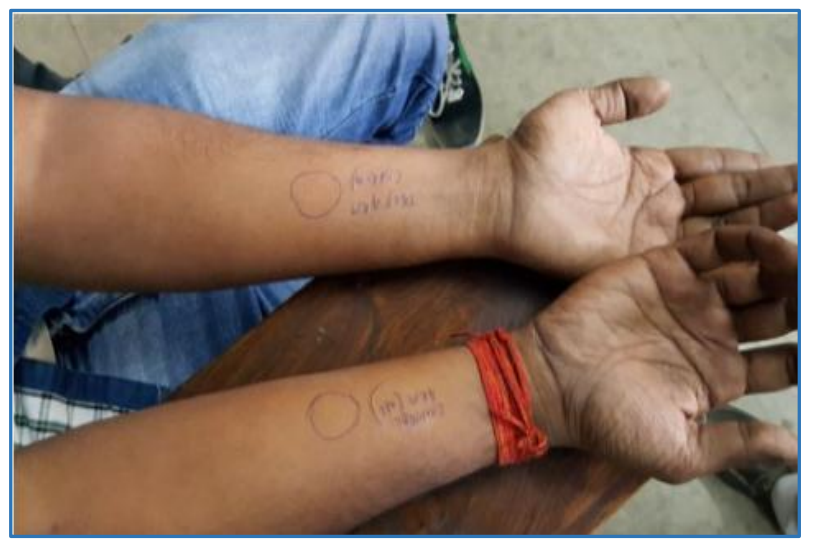

Autologous Serum Skin Test given

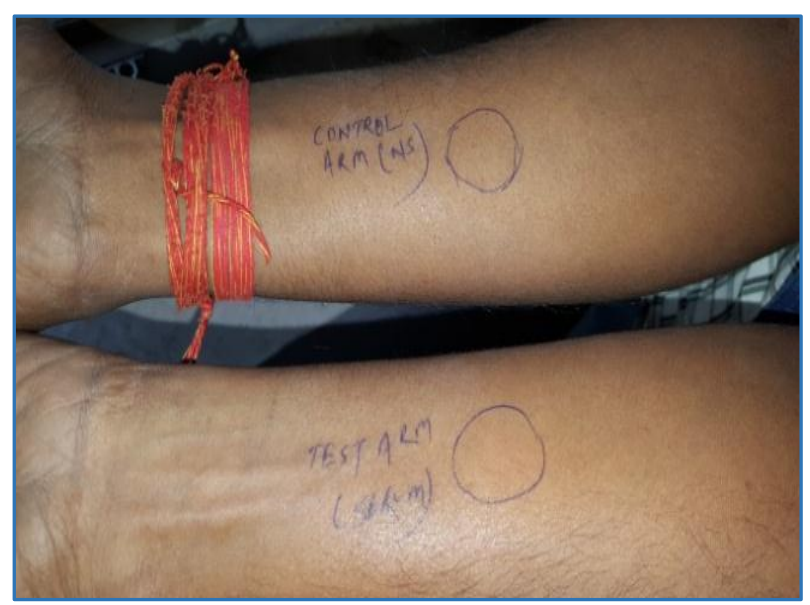

Autologous Serum Skin Test Negative

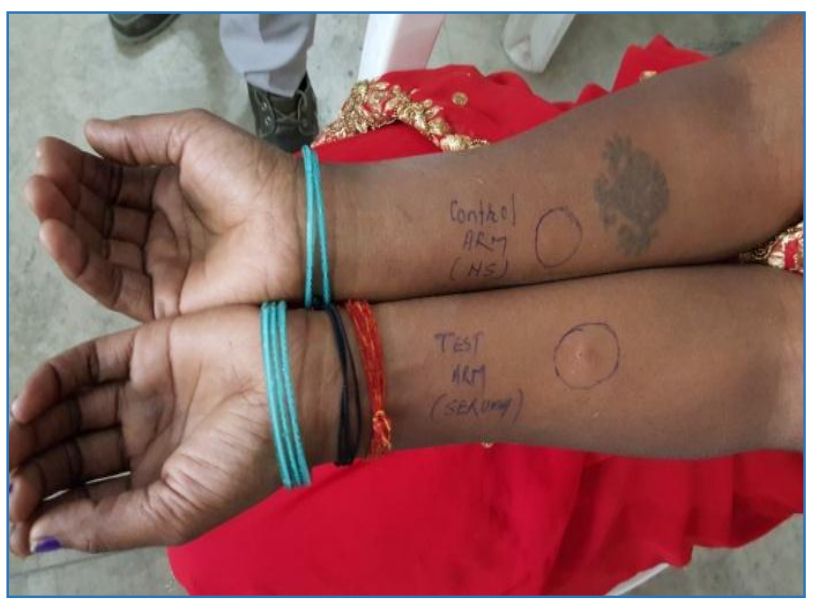

Autologous Serum Skin Test given 


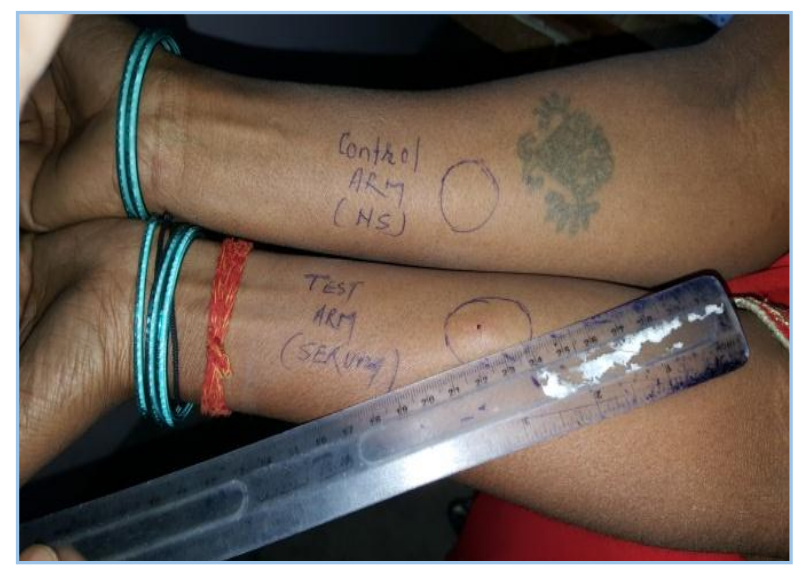

Autologous Serum Skin Test Positive

Autologous serum therapy was performed by withdrawing $5 \mathrm{~mL}$ blood in disposable syringe under aseptic precaution. Blood is then transferred to disposable vacutainers and centrifuged at 2000rpm for 10 minutes; $2 \mathrm{~mL}$ serum separated with help of disposable syringe, then injected intramuscularly at buttock. Treatment repeated every week.

Assessment Parameters.9,10

- Urticaria activity score.

- Urticaria total severity score.

- Antihistamine score.

- $\quad$ Likert scale.

- Dermatological quality of Life Index.

\section{Urticaria Activity Score}

Wheal

Score

0 -none

1 - Mild (20 wheal/24-hour)

2 - Moderate (20-50 wheals/24-hour)

3 - Intense ( $>50$ wheals/24-hour)

\section{Pruritus}

Score

0 -none

1 - Mild (present but not annoying/troublesome)

2 - Troublesome but does not interfere with sleep

3 - Severe pruritus, which is sufficiently troublesome to interfere with normal daily activity or sleep

Weekly urticaria activity score is calculated by adding daily UAS for 1 week, so score ranges from 0-42.

\footnotetext{
Urticaria Total Severity Score

1. Number and size of wheals,

2. Intensity of pruritus, score being 18.

5-point Likert scale

0 : No improvement,

1: Mild improvement,

2: Moderate improvement,

3: Marked improvement,
}

3. Duration of persistence of lesions,

4. Frequency of appearance of lesions,

5. Frequency of antihistamine use,

- With each parameter having a score of 0-3, maximum
4: Excellent improvement.

Antihistamine score

0 - no pill/week

1 - once/week

2 - 2-3 times/week

3 - daily

\section{DERMATOLOGY LIFE QUALITY INDEX}

Consists of series of questionnaires related to daily routine of life. Each parameter is scored as very much, a lot, a little, not at all and not relevant and score as 3, 2, 1 and 0. Total score ranges from 0-30. Each parameter was documented at 0, 2, 4, 6,8 and $10^{\text {th }}$ week.

\section{Statistical Analysis}

Statistical test - $t$ test and null hypothesis

\section{RESULTS}

\begin{tabular}{|c|c|c|c|}
\hline & $\begin{array}{c}\text { Autologous } \\
\text { Serum } \\
\text { Skin Test } \\
\text { Positive }\end{array}$ & $\begin{array}{c}\text { Autologous } \\
\text { Serum Skin } \\
\text { Test } \\
\text { Negative }\end{array}$ & Total \\
\hline Group 1 & $74(65.48 \%)$ & $39(34.52 \%)$ & $113(100 \%)$ \\
\hline Group 2 & $69(64.49 \%)$ & $38(35.51 \%)$ & $107(100 \%)$ \\
\hline Total & $\mathbf{1 4 3 ( 6 5 \% )}$ & $\mathbf{7 7}(\mathbf{3 5 \% )}$ & $\mathbf{2 2 0}(\mathbf{1 0 0 \% )}$ \\
\hline \multicolumn{2}{|c|}{ Table 1: Autologous Serum Skin Test Results } \\
\hline
\end{tabular}

In this study in Group 1, out of 113 patients (100\%) 74 patients (65.48\%) were Autologous Serum Skin Test positive and 39 patients (34.52\%) were Autologous Serum Skin Test negative. In Group 2, out of 107 patients (100\%), 69 patients (64.49\%) were Autologous Serum Skin Test positive and 38 patients (35.52\%) were Autologous Serum Skin Test negative. Overall, 65\% patients were Autologous Serum Skin Test positive.

\begin{tabular}{|c|c|c|c|}
\hline & Male & Female & Total \\
\hline Group 1 & $41(36.28 \%)$ & $72(63.72 \%)$ & $113(100 \%)$ \\
\hline Group 2 & $38(35.51 \%)$ & $69(64.49 \%)$ & $107(100 \%)$ \\
\hline Total & $\mathbf{7 9}(\mathbf{3 5 . 9 1 \% )}$ & $\mathbf{1 4 1}(\mathbf{6 4 . 0 9 \% )}$ & $\mathbf{2 2 0}(\mathbf{1 0 0} \%)$ \\
\hline \multicolumn{3}{|c|}{ Table 2: Distribution of Subjects According to Sex } \\
\hline
\end{tabular}

Out of 220 patients, 79 patients were male and rest 141 patients were female. On percentage basis, $35.51 \%$ were male and rest $64.09 \%$ were female. In group 141 patients $(36.28 \%)$ were male and 72 patients $(63.72 \%)$ were female. In Group 2, 38 patients (35.91\%) were male and 69 patients $(64.49 \%)$ were female.

\begin{tabular}{|c|c|c|c|c|c|c|}
\hline $\begin{array}{c}\text { Sl. } \\
\text { No. }\end{array}$ & $\begin{array}{c}\text { Age } \\
\text { Group }\end{array}$ & Female & $\%$ & Male & $\%$ & Total (\%) \\
\hline 1 & $\begin{array}{c}18-20 \\
\text { year }\end{array}$ & 18 & $\begin{array}{c}12.58 \\
\%\end{array}$ & 10 & $12.98 \%$ & $\begin{array}{c}28 \\
(12.73 \%)\end{array}$ \\
\hline 2 & $\begin{array}{c}20-30 \\
\text { year }\end{array}$ & 45 & $\begin{array}{c}31.47 \\
\%\end{array}$ & 24 & $31.17 \%$ & $\begin{array}{c}69 \\
(31.36 \%)\end{array}$ \\
\hline 3 & $\begin{array}{c}30-40 \\
\text { year }\end{array}$ & 38 & $\begin{array}{c}26.95 \\
\%\end{array}$ & 23 & $29.11 \%$ & $\begin{array}{c}61 \\
(27.73 \%)\end{array}$ \\
\hline 4 & $\begin{array}{c}40-50 \\
\text { year }\end{array}$ & 18 & $\begin{array}{c}12.59 \\
\%\end{array}$ & 14 & $18.18 \%$ & $\begin{array}{c}32 \\
(14.55 \%)\end{array}$ \\
\hline 5 & $\begin{array}{c}50-60 \\
\text { year }\end{array}$ & 22 & $\begin{array}{c}15.38 \\
\%\end{array}$ & 8 & $10.39 \%$ & $\begin{array}{c}30 \\
(13.64 \%)\end{array}$ \\
\hline Total & \multicolumn{7}{|c|}{$\mathbf{1 4 1}$} & $\begin{array}{c}\mathbf{1 0 0} \\
\%\end{array}$ & $\mathbf{7 9}$ & $\mathbf{1 0 0 \%}$ & $\begin{array}{c}\mathbf{2 2 0} \\
(\mathbf{1 0 0} \%)\end{array}$ \\
\hline \multicolumn{7}{|c|}{ Table 3: Distribution of Study Subjects According to Age } \\
\hline
\end{tabular}

Out of 220 patients, 18 (12.58\%) female and 10 male $(12.98 \%)$ belong to age group 18 to 20 years; 45 (31.47\%) 
female and 24 male (31.17\%) belong to age group 20 to 30 years; 38 (26.95\%) female and 23 male (29.11\%) belong to age group 30 to 40 years; 18 (12.59\%) female and 14 male (18.18\%) belong to age group 40 to 50 years; $22(15.38 \%)$ female and 8 male (10.39\%) belong to age group 50 to 60 years. Most patient belong to $20-30$ years (31.36\%) and 30-40 years age group $(27.73 \%)$.
Out of total 220 patients, 89 patients (40.45\%) belong to rural area and 131 patients (59.55\%) belong to urban population. In Group 1, $36(16.36 \%)$ patients were from rural background and $43(19.55 \%)$ were from urban background. In Group 2, 53 (24.09\%) patients were from rural area and 88 $(40 \%)$ were from urban area.

\begin{tabular}{|c|c|c|c|}
\hline Sl. No. & Rural & Urban & Total \\
\hline Male & $36(16.36 \%)$ & $43(19.55 \%)$ & $79(35.91 \%)$ \\
\hline Female & $53(24.09 \%)$ & $88(40 \%)$ & $141(64.09 \%)$ \\
\hline Total & $\mathbf{8 9 ( 4 0 . 4 5 \% )}$ & $\mathbf{1 3 1}(\mathbf{5 9 . 5 5 \% )}$ & $\mathbf{2 2 0}(\mathbf{1 0 0} \%)$ \\
\hline \multicolumn{2}{|r|}{ Table 4: Distribution of Study Subjects According to Residence } \\
\hline
\end{tabular}

\begin{tabular}{|c|c|c|c|c|c|c|c|c|}
\hline $\begin{array}{c}\text { Sl. } \\
\text { No. }\end{array}$ & Parameter & $\begin{array}{c}\text { (n=74) } \\
\text { Mean } \\
\text { (Starting of } \\
\text { Therapy) }\end{array}$ & $\begin{array}{c}\text { (n=74) } \\
\text { SD }\end{array}$ & $\begin{array}{c}\mathbf{c}=74) \\
\text { Mean } \\
\text { (End of } \\
\text { Therapy) }\end{array}$ & $\begin{array}{c}\text { (n=74) } \\
\text { SD }\end{array}$ & $\begin{array}{c}\text { t- } \\
\text { value }\end{array}$ & P value & Significance \\
\hline 1 & UAS & 28.00 & 3.29 & 26.11 & 3.96 & 3.159 & 0.0019 & Significant \\
\hline 2 & UTSS & 14.39 & 1.57 & 12.64 & 1.19 & 7.68 & 0.0001 & Significant \\
\hline 3 & Antihistamine score & 3 & 0 & 2.38 & 0.62 & 8.62 & 0.0001 & Significant \\
\hline 4 & DQLI & 19.69 & 2.11 & 17.93 & 2.92 & 4.196 & 0.0001 & Significant \\
\hline
\end{tabular}

In Autologous serum skin test positive patients of Group 1, null hypothesis and unpaired ' $\mathrm{t}$ ' test applied for urticaria activity score, urticaria total severity score, antihistamine score and dermatological quality of life index. Test shown significant improvement ( $p$ value $<0.05$ ) in all parameters after treatment.

\begin{tabular}{|c|c|c|c|c|c|c|c|c|}
\hline Sl. No. & Parameter & $\begin{array}{c}\text { (n=39) } \\
\text { Mean } \\
\text { (Starting } \\
\text { of } \\
\text { Therapy) }\end{array}$ & $\begin{array}{c}\text { (n=39) } \\
\text { SD }\end{array}$ & $\begin{array}{c}\text { (n=39) } \\
\text { Mean } \\
\text { (End of } \\
\text { Therapy) }\end{array}$ & $\begin{array}{c}\text { (n=39) } \\
\text { SD }\end{array}$ & t-value & P value & Significance \\
\hline 1 & UAS & 28.13 & 3.31 & 26.31 & 3.86 & 3.159 & 0.0019 & Significant \\
\hline 2 & UTSS & 14.82 & 1.70 & 13.56 & 3.21 & 2.16 & 0.0339 & Significant \\
\hline 3 & $\begin{array}{c}\text { Antihistamine } \\
\text { score }\end{array}$ & 3 & 0 & 2.55 & 0.096 & 4.71 & 0.0001 & Significant \\
\hline 4 & \multicolumn{2}{|l|}{ DQLI } \\
\hline
\end{tabular}

In Autologous serum skin test negative patients of Group 1, null hypothesis and unpaired ' $\mathrm{t}$ ' test applied for urticaria activity score, urticaria total severity score, antihistamine score and dermatological quality of life index. Test shown significant improvement ( $p$ value $<0.05$ ) in all parameters after treatment.

\begin{tabular}{|c|c|c|c|c|c|c|c|c|}
\hline Sl. No. & Parameter & $\begin{array}{c}\text { (n=69) } \\
\text { Mean } \\
\text { (Starting of } \\
\text { Therapy) }\end{array}$ & $\begin{array}{c}\text { (n=69) } \\
\text { SD }\end{array}$ & $\begin{array}{c}\text { (n=69) } \\
\text { Mean } \\
\text { (End of } \\
\text { Therapy) }\end{array}$ & $\begin{array}{c}\text { (n=69) } \\
\text { SD }\end{array}$ & t- value & $\begin{array}{c}\text { P } \\
\text { value }\end{array}$ & Significance \\
\hline 1 & UAS & 29.50 & 3.21 & 28.13 & 3.70 & 1.7220 & 0.0892 & $\begin{array}{c}\text { Not } \\
\text { Significant }\end{array}$ \\
\hline 2 & UTSS & 14.82 & 1.70 & 13.56 & 3.21 & 2.16 & 0.0339 & $\begin{array}{c}\text { Not } \\
\text { Significant }\end{array}$ \\
\hline 3 & Antihistamine score & 3 & 0 & 2.96 & 0.0810 & 1.76 & 0.083 & $\begin{array}{c}\text { Not } \\
\text { Significant }\end{array}$ \\
\hline 4 & DQLI & 21.14 & 1.96 & 20.48 & 2.36 & 1.81 & 0.0732 & Not \\
Significant
\end{tabular}

In Autologous serum skin test positive patients of Group 2, null hypothesis and unpaired ' $t$ ' test applied for urticaria activity score, urticaria total severity score, antihistamine score and dermatological quality of life index. Test does not show significant improvement ( $\mathrm{p}$ value $>0.05$ ) in all parameters after treatment. 


\begin{tabular}{|c|c|c|c|c|c|c|c|c|}
\hline $\begin{array}{l}\text { Sl. } \\
\text { No. }\end{array}$ & Parameter & $\begin{array}{c}(n=38) \\
\text { Mean } \\
\text { (Starting of } \\
\text { Therapy) }\end{array}$ & $\begin{array}{c}(n=38) \\
\text { SD }\end{array}$ & $\begin{array}{c}\text { (n=38) Mean } \\
\text { (End of } \\
\text { Therapy) }\end{array}$ & $\begin{array}{c}(n=38) \\
\text { SD }\end{array}$ & $\begin{array}{c}\text { t- } \\
\text { value }\end{array}$ & $\begin{array}{c}\mathbf{P} \\
\text { value }\end{array}$ & Significance \\
\hline 1 & UAS & 29.50 & 3.21 & 28.13 & 3.70 & 1.7220 & 0.0892 & $\begin{array}{c}\text { Not } \\
\text { Significant }\end{array}$ \\
\hline 2 & UTSS & 14.24 & 1.34 & 13.76 & 1.55 & 1.42 & 0.1589 & $\begin{array}{c}\text { Not } \\
\text { Significant }\end{array}$ \\
\hline 3 & $\begin{array}{l}\text { Antihistamine } \\
\text { score }\end{array}$ & 3 & 0 & 2.95 & 0.23 & 1.43 & 0.156 & $\begin{array}{c}\text { Not } \\
\text { Significant }\end{array}$ \\
\hline 4 & DQLI & 21.13 & 2.09 & 20.32 & 2.26 & 1.6338 & 0.1086 & $\begin{array}{c}\text { Not } \\
\text { Significant }\end{array}$ \\
\hline
\end{tabular}

In Autologous serum skin test negative patients of Group 2, null hypothesis and unpaired ' $t$ ' test applied for urticaria activity score, urticaria total severity score, antihistamine score and dermatological quality of life index. Test does not show significant improvement ( $\mathrm{p}$ value $>0.05$ ) in all parameters after treatment.

\begin{tabular}{|c|c|c|c|c|}
\hline & \multicolumn{2}{|c|}{ Group 1 } & \multicolumn{2}{c|}{ Group 2 } \\
\hline & $\begin{array}{c}\text { Autologous Serum } \\
\text { Skin Test Positive }\end{array}$ & $\begin{array}{c}\text { Autologous Serum } \\
\text { Skin Test Negative }\end{array}$ & $\begin{array}{c}\text { Autologous Serum } \\
\text { Skin Test Positive }\end{array}$ & $\begin{array}{c}\text { Autologous Serum } \\
\text { Skin Test Negative }\end{array}$ \\
\hline No improvement & $20(27.02 \%)$ & $14(35.89 \%)$ & $34(49.28 \%)$ & $18(47.37 \%)$ \\
\hline $\begin{array}{c}\text { Mild } \\
\text { improvement }\end{array}$ & $23(31.08 \%)$ & $12(30.77 \%)$ & $29(42.03 \%)$ & $17(44.74 \%)$ \\
\hline $\begin{array}{c}\text { Moderate } \\
\text { improvement }\end{array}$ & $19(25.68 \%)$ & $8(20.51 \%)$ & $6(8.70 \%)$ & $3(7.90 \%)$ \\
\hline $\begin{array}{c}\text { Marked } \\
\text { improvement }\end{array}$ & $8(10.81 \%)$ & $4(10.26 \%)$ & $0(0 \%)$ & $0(0 \%)$ \\
\hline $\begin{array}{c}\text { Excellent } \\
\text { improvement }\end{array}$ & $4(5.41 \%)$ & $1(2.56 \%)$ & $0(0 \%)$ & $0(0 \%)$ \\
\hline Total & $\mathbf{7 4 ( 1 0 0 \% )}$ & $\mathbf{3 9 ( 1 0 0 \% )}$ & $\mathbf{6 9}(\mathbf{1 0 0} \%)$ & $\mathbf{3 8 ( 1 0 0 \% )}$ \\
\hline \multicolumn{5}{c}{ Table 9: Likert Scale } \\
\hline
\end{tabular}

In Group 1 out of 74 Autologous serum skin test positive patients, 20 patients $(27.02 \%)$ shown no improvement, 23 patients $(31.08 \%)$ shown mild improvement, 19 patients (25.68\%) shown moderate improvement, 8 patients (10.81\%) shown marked improvement and 4 patients (5.41\%) shown excellent improvement.

In Group 1 out of 39 Autologous serum skin test negative patients, 14 patients (35.89\%) shown no improvement, 12 patients $(30.77 \%)$ shown mild improvement, 8 patients (20.51\%) shown moderate improvement, 4 patients $(10.26 \%)$ shown marked improvement and 1 patient (2.56\%) shown excellent improvement.

In Group 2, out of 69 Autologous serum skin test positive patients, 34 patients (49.28\%) shown no improvement, 29 patients $(42.03 \%)$ shown mild improvement, 6 patients $(8.70 \%)$ shown moderate improvement, no patient shown marked or excellent improvement.

In Group 2, out of 38 Autologous serum skin test negative patients, 18 patients (47.37\%) shown no improvement, 17 patients (44.74\%) shown mild improvement, 3 patients (7.90\%) shown moderate improvement, no patient shown marked or excellent improvement.

\section{DISCUSSION}

Urticaria is characterized by transient skin or mucosal swellings due to plasma leakage. Wheals are characteristically pruritic and pink or pale in the center. ${ }^{1}$

All urticarias are acute initially. Some will become chronic after a period of time that is usually defined as 6 weeks or more. ${ }^{2}$
Estimates of the lifetime occurrence of urticaria range from less than $1 \%$ to as high as $30 \%$ in the general population, depending on the age range and method of sampling. The true figure is likely to be in the range of $1-5 \% .^{1}$

Overall, urticaria is more common in women with a female:male ratio of approximately $2: 1$ for chronic urticaria, but the ratio varies with the different physical urticarias. ${ }^{1}$

The mast cell is the primary effector cell of urticaria. Cross-linking of two or more adjacent FceRI on the mast cell membrane will initiate a chain of calcium- and energydependent steps leading to fusion of storage granules with the cell membrane and externalization of their contents. This is known as degranulation. ${ }^{11}$

Classic immediate hypersensitivity reactions involve binding of receptor-bound specific IgE by allergen. There are several recognized immunologic degranulating stimuli that act through the $\operatorname{IgE}$ receptor, such as anti-IgE and anti-FceRI antibodies. ${ }^{12}$ Other non-immunologic stimuli including opiates, C5a anaphylatoxin, stem cell factor and some neuropeptides (e.g. substance P) can cause mast cell degranulation by binding specific receptors, independent of the FceRI. Mast cell granules contain preformed mediators of inflammation, the most important of which is histamine. 13

Histamine and other proinflammatory mediators released on degranulation bind receptors on post-capillary venules in the skin leading to vasodilatation and increased permeability to large plasma proteins including albumin and immunoglobulins. Furthermore, histamine, TNF- $\alpha$ and IL-8 upregulate the expression of adhesion molecules on endothelial cells, thereby promoting the migration of 
circulating inflammatory cells from the blood into the urticarial lesion. ${ }^{13}$

Functional IgG autoantibodies that release histamine (And other mediators) from mast cells and basophils have been detected in the serum of $30-50 \%$ of patients with chronic 'ordinary' urticaria using in vitro assays. ${ }^{11}$ Sera of approximately $60 \%$ of patients with chronic ordinary urticaria have been shown to cause a pink wheal when injected intradermally into the patient's own skin (The autologous serum skin test). ${ }^{8}$ In our study, $65 \%$ patients shown positive Autologous serum skin test. Antihistamines are the mainstay of management. This is first line treatment for urticaria. ${ }^{2}$ The use of serum in place of whole blood is the modification that has been used by Bajaj, et al. ${ }^{3}$

Whole blood therapy had been tried in many autoimmune diseases including pemphigus, severe dry eye (Due to Sjogren's syndrome, rheumatoid arthritis, etc.) and diseases like viral illness like herpes, cancer, allergic diseases like atopic dermatitis. ${ }^{14,15,16,17}$ Potential of whole blood in the treatment of urticaria was documented by Fleck M. ${ }^{18}$ and Stuabach et al. ${ }^{14}$ in separate studies and later use of serum in the treatment of urticaria was highlighted by Bajaj, et al. ${ }^{3}$ The plausible mechanism of action of autologous serum therapy was thought to be induction of anti-idiotypes, which have recently been shown to inhibit the function of diseaseinducing antibodies in pemphigus and also to shift the Th2 cytokine profile to Th1 in Autologous serum skin test + patients. ${ }^{14}$

Different studies had been conducted on autologous serum therapy. Staubach, et al. ${ }^{14}$ reported improvement in $70 \%$ Autologous serum skin test positive patients. Bajaj, et al. ${ }^{3}$ reported improvement in $60 \%$ Autologous serum skin test positive patients. Panchami Debbarman et al. ${ }^{7}$ also found Autologous serum therapy beneficial in chronic urticaria. Sharmila Patil, et al. ${ }^{6}$ gave autologous serum therapy to 20 patients excellent improvement was seen in 9 patients, 6 patients did not show satisfactory response and five patients showed no response. In our study, $41.9 \%$ Autologous serum skin test positive patient and $33.33 \%$ Autologous serum skin test negative patients shown moderate-to-excellent improvement.

\section{CONCLUSION}

Autologous serum therapy is proved effective in chronic urticaria patients, specially in Autologous serum skin test positive patients.

\section{ACKNOWLEDGMENT}

The study was conducted in the Department of Dermatology of the institution. Support was provided by professors, residents and staff.

\section{REFERENCES}

1. Schäfer T, Ring J. Epidemiology of urticaria. Monogr Allergy 1993;31:49-60.

2. Henz BM, Zuberbier T, Grabbe J, Monroe E, eds. Urticaria: Clinical, Diagnostic and Therapeutic Aspects. Berlin: Springer 1998;55-89.
3. Bajaj AK, Saraswat A, Upadhyay A, et al. Autologous serum therapy in chronic urticaria: old wine in a new bottle. Indian J Dermatol Venereol Leprol 2008;74:109-13.

4. Chopra A, Mamta, Chopra D. Autohaemotherapy in chronic urticaria. Indian J Dermatol Venereol Leprol 1995;61:3234.

5. Kocaturk E, Aktas S, Türkoğlu Z, et al. Autologous whole blood and autologous serum injections are equally effective as placebo injections in reducing disease activity in patients with chronic spontaneous urticaria: a placebo controlled, randomized, single-blind study. J Dermatolog Treat 2012;23:465-71.

6. Sharmila Patil, Nidhi Sharma and Kiran Godse. Department of Dermatology, Dr. D.Y. Patil Medical College and Hospital, Nerul, Navi Mumbai, India Autologous Serum Therapy in Chronic Urticaria. Indian J Dermatol 2013 May-Jun; 58(3):225-226.

7. Panchami Debbarman1, Amrita Sil2, Piyush Kanti Datta3, et al. Autologous serum therapy in chronic urticaria: a promising complement to antihistamines. Indian J Dermatol Year : 2014 | Volume : 59 | Issue : 4 | Page : 375382.

8. Sabroe R, et al. The autologous serum skin test: a screening test for autoantibodies in chronic idiopathic urticaria. Br J Dermatol 140:446, 1999.

9. Maurer M, Ortonne JP, Zuberbier T. Chronic urticaria: a patient survey on quality-of-life, treatment usage and doctor-patient relation. Allergy 2009;64:581-8.

10. Grob JJ, Gaudy-Marqueste C. Urticaria and quality of life. Clin Rev Allergy Immunol 2006;30:47-51.

11. Dreskin SC, ed. Urticaria [special issue]. Immunol Allergy Clin N Am 2004;24(2).

12. Gruber BL, Baeza M, Marchese M, et al. Prevalence and functional role of anti-IgE autoantibodies in urticaria syndromes. J Invest Dermatol 1988;90:213-217.

13. Grattan CEH, Wallington TB, Wurin RP, et al. A serological mediator in chronic idiopathic urticaria. A clinical, immunological and histological evaluation. Br J Dermatol 1986;114:583-590.

14. Staubach P, Onnen K, Vonend A, et al. Autologous whole blood injections to patients with chronic urticaria and a positive autologous serum skin test: A placebo-controlled trial. Dermatology 2006;212:150-9.

15. Bocci V. Autohaemotherapy after treatment of blood with ozone. A reappraisal. J Int Med Res 1994;22:131-44.

16. Pittler MH, Armstrong NC, Cox A, et al. Randomized, double-blind, placebo-controlled trial of autologous blood therapy for atopic dermatitis. Br J Dermatol 2003;148:30713.

17. Olwin JH, Ratajczak HV, House RV. Successful treatment of herpetic infections by autohemotherapy. J Altern Complement Med 1997;3:155-8.

18. Fleck M. Urticaria. In: Gottron H, Schönfeld W, editors. Dermatologie und Venerologie. Vol 3. Stuttgart: Thieme; 1959, p. 265-98. 